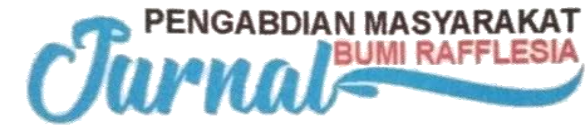

\section{PELATIHAN KETRAMPILAN DASAR KOMPUTER, OFFICE DAN INTERNET BAGI PERANGKAT DESA PADANG PELASAN KECAMATAN AIR PERIUKAN KABUPATEN SELUMA}

\author{
Agusdi Syafrizal*, Rozali Toyib, Yulia Darnita \\ Program Studi Studi Teknik Informatika, Fakultas Teknik, Universitas Muhammadiyah Bengkulu \\ *Corresponding author: agusdisyafrizal@umb.ac.id
}

\begin{abstract}
ABSTRAK
Desa Padang Pelasan termasuk dalam daerah administratif Kabupaten Seluma yang hampir mayoritas penduduknya bertani dan mempunyai persawaan untuk menompang kehidupan mereka sehari-hari. Umumnya pertanian berupa tanaman keras yaitu karet dan kelapa sawit, Keadaan Ekonomi Masyarakat Desa Padang Pelasan Hanya 2 Kategori. $50 \%$ Menengah keatas dan $40 \%$ Menengah ke bawah. Dalam kegiatan adminitrasi yang dilakukan masih dilakukan secara konvensional dan hampir semua data masih berupa dokumentasi tertulis sehingga menyulitkan bila data yang mau dicari data yang sudah lama, banyak aparat desa yang masih gaptek dengan teknologi saat ini yaitu komputer dan internet sehingga kegiatan administrasi desa jadi terhambat, sedangkan saat ini banyaknya program dari pusat harus segera diimplementasikan dan membutuh data dari desa dan hampir semua informasi melalui situs web, mulai pengusulan, informasi biaya dan pelaporan melalui website resmi dari pusat. Teknologi komputer membuat pekerjaan di bidang administrasi baik itu perusahaan ataupun kantor menjadi lebih mudah, sektor inipun berkembang begitu pesat dan sekarang ini hampir disetiap bidang menggunakan komputer sebagai alat bantu dalam mengerjakan banyak hal apa lagi ditemukan teknologi komunikasi yang memungkinkan pertukaran informasi yang cepat, baik secara langsung maupun tidak langsung karena itulah teknologi komunikasi menjadi sangat penting. Berdasarkan hasil Pengabdian Masyarakat yang dilakukan dapat diambil kesimpulan : Adanya Peningkatan dalam melakukan pekerjaan administrasi dan keuangan desa, Internet menjadi bagian penting bagi mereka untuk memperoleh informasi penting, Keterbatasan prasarana khususnya perangkat komputer yang ada di Kantor Desa.
\end{abstract}

Kata Kunci: administrasi, internet, komputer, teknologi

\section{PENDAHULUAN}

\subsection{Deskripsi Wilayah}

Untuk menuju Indonesia yang berdaulat secara politik, mandiri dalam bidang ekonomi dan berkepribadian dalam kebudayaan, dengan membangun Indonesia dari pinggiran dengan memperkuat daerah-daerah dan desa dalam kerangka negara kesatuan harus dipahami dalam perspektif yang utuh, dalam hal ini sebagai afirmasi untuk mendorong kegiatan sosialekonomi dan pembanguna wilayah 
pinggiran yang selama ini kurang diproritaskan pemerintah, hal tersebut selaras dengan salah satu misi pembangunan nasional yang tertuang dalam Undang-Undang Nomor 17 Tahun 2007 tentang Rencana Pembangunan Jangka Menengah Nasional (RPJMN) tahu 2005-2025, yakni mewujudkan pemerataan pembangunan dan berkeadilan dengan meningkatkan pembangunan daerah, mengurangi kesenjangan sosial secara menyeluruh dengan meningkatkan keberpihakkan kepada masyarakat, kelompok dan wilayah/daerah yang masih lemah; menanggulangi kemiskinan dan pengganggurn secara drastis; menyediakan akses yang sama bagi masyarakat terhadap berbagai pelayanan sosial serta sarana dan prasarana ekonomi.

Kabupaten Seluma adalah salah satu daerah dalam provinsi Bengkulu yang beribukotakan di Tais. Kabupaten Seluma secara administrasi termasuk kedalam wilayah provinsi Bengkulu yang di bentuk berdasarkan UndangUndang Nomor 03 Tahun 2003, tentang pembentukan kabupaten Mukomuko, kabupaten Seluma dan kabupaten Kaur. Secara Geografis Kabupaten Seluma terletak di Pantai Barat Sumatera Bagian Selatan yang berada pada koordinat garis lintang dan bujur yaitu 030 49'55,66"- 040 21'40,22" LS dan 1010 017' 27,57"1020 59'40,54" BT. Kabupaten Seluma merupakan kabupaten yang wilayahnya seluas $240.044 \mathrm{~km} 2$ yang terletak pada ketinggian $0->1.000$ meter dari permukaan laut.

Luas wilayah darat Kabupaten Seluma menurut Undang-Undang Nomor 3 Tahun 2003 adalah seluas \pm $2.400,44 \mathrm{~km}^{2}$ atau $12,13 \%$ dari luas Provinsi Bengkulu dan wilayah laut seluas $\pm 1.728,02 \mathrm{~km}^{2}$ sehingga total keseluruhan luas Kabupaten Seluma adalah 4.128,46 $\mathrm{km}^{2}$. Dalam perkembangannya sesuai dengan rencana pengembangan wilayah dan aspirasi dari masyarakat, maka Kabupaten Seluma memekarkan Kecamatan Induk dari 5 Kecamatan menjadi 14 Kecamatan.

Dilihat dari sudut pandang letak Kabupeten Seluma, posisi Kabupaten Seluma sangat stategis karena disamping dilewati jalur Jalan Lintas Sumatera juga daerahnya berbatasan langsung dengan Kota Bengkulu selaku ibukota Provinsi Bengkulu.

Topografinya bervariasi mulai dari tepi pantai dan dataran rendah pada Kecamatan Sukaraja, Kecamatan Seluma Selatan, Kecamatan Ilir Talo dan Kecamatan Semidang Alas Maras sampai pada daerah perbukitan dan pegunungan pada Kecamatan Ulu Talo dan Kecamatan Semidang Alas. Disamping itu dikabupaten Seluma terutama sekali di Kecamatan Sukaraja, Air Periukan, Seluma Selatan dan Ilir Talo banyak dijumpai rawa-rawa.

Desa Padang Pelasan termasuk dalam daerah administratif Kabupaten Seluma yang hampir mayoritas penduduknya bertani dan mempunyai persawaan untuk menompang kehidupan mereka sehari-hari. Umumnya pertanian berupa tanaman keras yaitu karet dan kelapa sawit, Keadaan Ekonomi Masyarakat Desa Padang Pelasan Hanya 2 Kategori. $50 \%$ Menengah keatas dan $40 \%$ Menengah ke bawah. Untuk mengecek ekonomi masyrakat desa maka di adakan pendataan ekonomi untuk menentukan warga ekonomi kebawah di hitung dari pendapataan perbulan serta mengecek Aset kepemilikan lainnya. Jarak desa Padang Pelasan dengan jalan lintas provinsi $\pm 1 \mathrm{~km}$, Akses jalan menuju desa berupa jalan koral dan sebagian jalan telah diaspal, Jarak desa ke kota provinsi adalah $37 \mathrm{~km}$ dengan waktu tempuh 63 menit dan Transportasi dari desa dan ke desa Padang Pelasan sudah cukup baik dan memadai. 
Tabel 2.3. Jumlah dan Kepadatan

Penduduk 3-5 tahun terakhir

\begin{tabular}{|c|c|c|c|c|c|c|c|c|c|c|c|c|}
\hline \multirow{3}{*}{ Nama Kesamitan } & \multicolumn{3}{|c|}{ Jumlab Pendudulk } & \multicolumn{3}{|c|}{ Jumlab KK } & \multicolumn{3}{|c|}{$\begin{array}{c}\text { Tighlat } \\
\text { Pertumbuban }\end{array}$} & \multicolumn{3}{|c|}{ Kepadatan pddlk } \\
\hline & \multicolumn{3}{|c|}{ Tabun } & \multicolumn{3}{|c|}{ Tabun } & \multicolumn{3}{|c|}{ Tabun } & \multicolumn{3}{|c|}{ Tabuu } \\
\hline & 2011 & 2012 & 2013 & 2011 & 2012 & 2013 & 2011 & 2012 & 2013 & 2011 & 2012 & 2013 \\
\hline Sulargja & 29.70 & 30203 & 32570 & 10354 & 10.668 & 10972 & 1,25 & 1.25 & 1.25 & 123,52 & 125,44 & 135,27 \\
\hline Air Periulan & 18526 & 18.812 & 19930 & 8561 & 8981 & 9.500 & 1.25 & 1,25 & 1.25 & 151,44 & 153,78 & 16292 \\
\hline LubukSandi & 9.681 & 9.832 & 10.719 & 3373 & 3.689 & 3.868 & 1.25 & 1,25 & 1.25 & 55.26 & 36,12 & 61,18 \\
\hline Seluma Barat & 7.798 & 7919 & 9.602 & 2890 & 2979 & 3267 & 1.25 & 1,25 & 1.25 & 76.12 & 77,30 & 93,72 \\
\hline Saluma & 8344 & 8.472 & 9.867 & 3.042 & 3256 & 3.461 & 1.25 & 1,25 & 1,25 & 382,23 & 388,09 & 451,99 \\
\hline Seluma Uara & 7.736 & 7857 & 11.963 & 3.567 & 3.890 & 4.091 & 1.25 & 1.25 & 1.25 & 18,83 & 19,12 & 29,11 \\
\hline Seluma Timur & 8901 & 9.038 & 10.109 & 3290 & 3590 & 3.995 & 1.25 & 1,25 & 1.25 & 138,00 & 140,12 & 156,73 \\
\hline Seluma Selann & 10588 & 10.751 & 12289 & 4239 & 4.678 & 4901 & 1,25 & 1,25 & 1.25 & 142,20 & 144,39 & 165,04 \\
\hline Talo & 10.591 & 10.754 & 11.690 & 3.890 & 4.120 & 4562 & 1,25 & 1.25 & 1.25 & 95,24 & 96,71 & 105,13 \\
\hline Talo Kecil & 9259 & 9.402 & 14321 & 3568 & 3.754 & 4.675 & 1.25 & 1.25 & 1.25 & 1549.91 & 15730 & 239,60 \\
\hline Ulu Talo & 4.816 & 4.891 & 10.889 & 2.154 & 2347 & 3.890 & 1.25 & 1,25 & 1.25 & 21.20 & 21,53 & 47.94 \\
\hline Iir Talo & 9.789 & 9.930 & 10529 & 3.887 & 4235 & 4569 & 1.25 & 1,25 & 1,25 & 74,51 & 75,58 & 80.14 \\
\hline SexidangAlas & 13591 & 13.803 & 15.423 & 4.678 & 4.889 & 4.997 & 1,25 & 1,25 & 1.25 & 24,50 & 24,88 & 27,80 \\
\hline $\begin{array}{l}\text { SenidangAlas } \\
\text { Naras }\end{array}$ & 20.801 & 21.122 & 22.161 & 4341 & 4.679 & 4981 & 1.25 & 1,25 & 1,25 & 200,49 & 203,39 & 213,60 \\
\hline
\end{tabular}

Sumber; Dinas Kependudukan dan Catatan Sipil Kabupaten Seluma 2014

Dalam kegiatan adminitrasi yang dilakukan masih dilakukan secara konvensional dan hampir semua data masih berupa dokumentasi tertulis sehingga menyulitkan bila data yang mau dicari data yang sudah lama, banyak aparat desa yang masih gaptek dengan teknologi saat ini yaitu komputer dan internet sehingga kegiatan administrasi desa jadi terhambat, sedangkan saat ini banyaknya program dari pusat harus segera diimplementasikan dan membutuh data dari desa dan hampir semua informasi melalui situs web, mulai pengusulan, informasi biaya dan pelaporan melalui website resmi dari pusat.

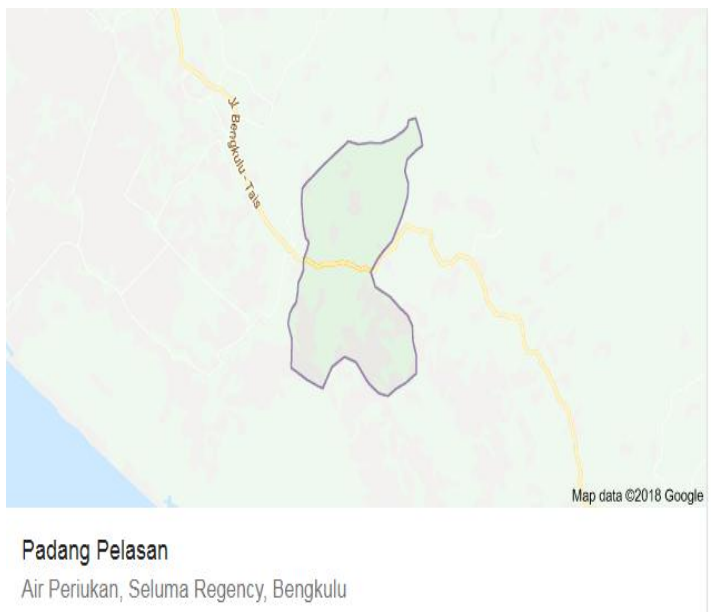

Gambar 1.1. Peta Desa Padang Pelasan

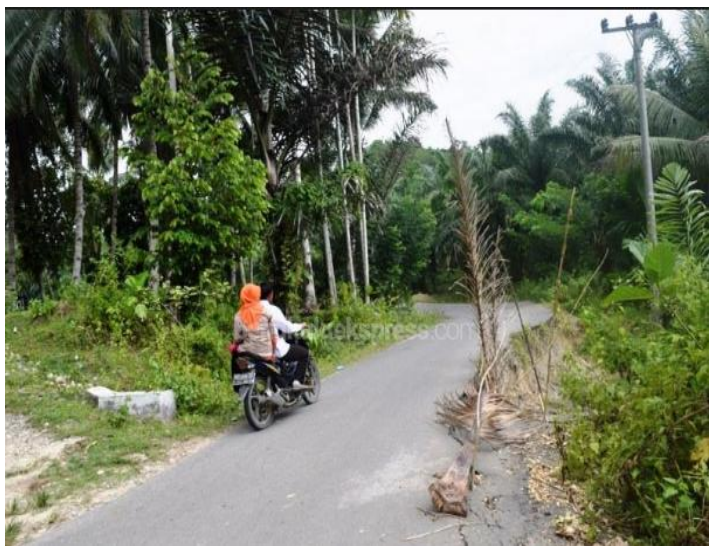

Gambar 1.2. Kondisi Wilayah

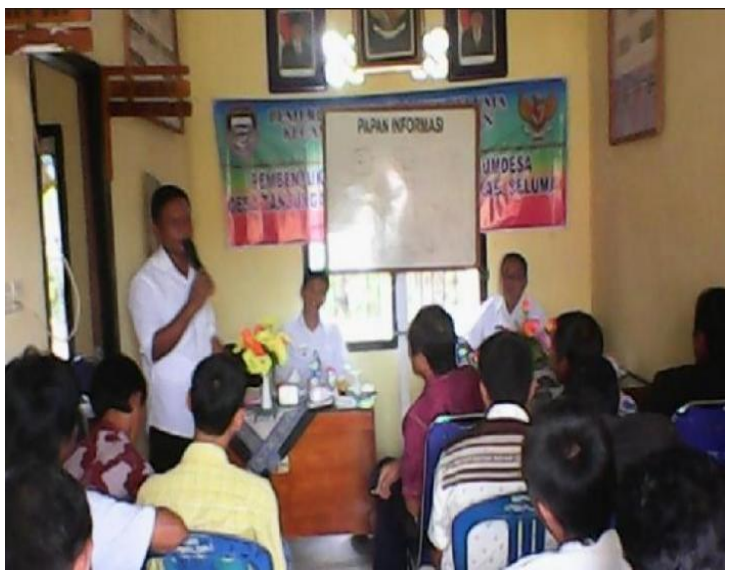

Gambar 1.3. Temu Desa

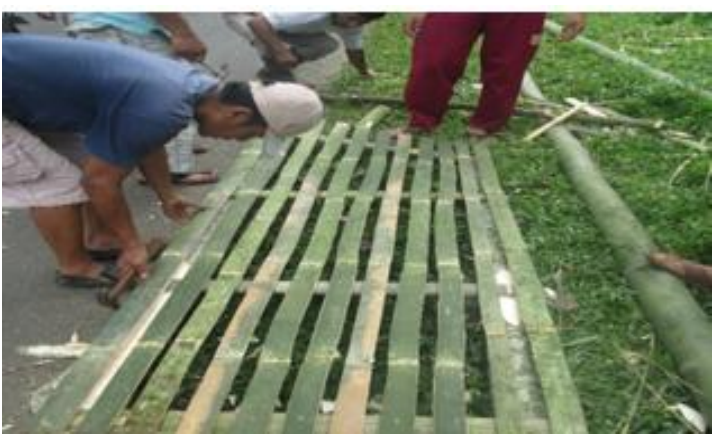


Gambar 1.4. Suasana Gotong Royong

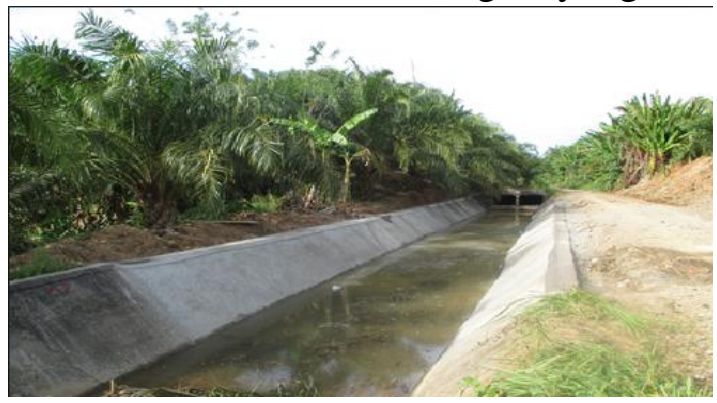

Gambar 1.5. Potensi Perkebunan Sawit dan Padi

\subsection{Permasalahan dan Usulan Penyelesaiannya}

Sebuah teknologi pada hakekatnya diciptakan untuk membuat hidup manusia menjadi lebih mudah dan nyaman, contohnya dengan ditemukan teknologi komputer membuat pekerjaan di bidang administrasi baik itu perusahaan ataupun kantor menjadi lebih mudah, sektor inipun berkembang begitu pesat dan sekarang ini hampir disetiap bidang menggunakan komputer sebagai alat bantu dalam mengerjakan banyak hal apa lagi ditemukan teknologi komunikasi yang memungkinkan pertukaran informasi yang cepat, baik secara langsung maupun tidak langsung karena itulah teknologi komunikasi menjadi sangat penting.

Kemajuan ilmu pengetahuan dan teknologi suatu bangsa tentu tidak terlepas dari keberhasilan proses pembelajaran di lembaga-lembaga serta institusi-institusi pendidikan tinggi di negara tersebut. Tahapan perubahan diharapkan mampu membawa bangsa ke arah kemajuan peradaban yang lebih tinggi dan meresap secara utuh sebagai jati diri bangsa tersebut. Tingkat penguasaan ilmu dan teknologi merupakan bukti nyata keberhasilan pembangunan. Peningkatan penguasaan ilmu dan teknologi tidak hanya dilakukan pada pendidikan formal, namun juga dapat dilakukan melalui pendidikan nonformal. Teknologi informasi memiliki perkembangan yang sangat pesat dan meliputi berbagai bidang.

Peran

Universitas

Muhammadiyah Bengkulu melalui Jurusan Teknik Informatika memiliki peran penting dalam meningkatkan proses belajar mengajar. Sesuai dengan visi dan misi dari Jurusan Teknik Informatika dalam perkembangan teknologi informasi diharapkan dapat memberikan hasil yang maksimal dengan adanya dukungan komponen masyarakat yang ada di wilayah Desa Padang Pelasan Kecamatan Air periukan Kabupaten Seluma.

Sesuai dengan judul program pengabdian masyarakat ini, metode penerapan ipteks yang dilakukan adalah berbentuk pendampingan untuk belajar dasar Komputer, MS Office dan Internet, Tujuan dari pelaksanaan program pengabdian masyarakat ini adalah:

1. Untuk memberikan tambahan aparat Desa Padang Pelasan Kecamatan Air Periukan Kabupaten Seluma

2. Untuk memberikan kontribusi pengelolaan administrasi dan Keuangan desa

3. Memberikan bekal yang nantinya bisa dikembangakan lebih baik untuk meningkatkan taraf kehidupan terutama ekonomi dengan menggunakan media Internet untuk memperoleh informasi dan perkembangan teknologi yang berhubungan dengan desa.

\section{METODE KEGIATAN}

\subsection{Waktu dan Tempat Pelaksanaan}

Pelaksanaan kegiatan pengabdian ini dilaksanakan dalam ruang balai kelurahan yang representative untuk kegiatan pelatihan ini, dalam menyampai materi, nara sumber menggunakan presentasi power 
point, pembagian modul dan metode tanya jawab.

A. Tempat/Waktu

1. Hari/Tanggal : Selasa/rabu 2022 Maret 2018

2. Tempat : Balai Desa Padang Pelasan Kecamatan Air Periukan Kabupaten Seluma

B. Jadwal Kegiatan

a. Persiapan :

1. Mengurus izin kepada Kepala Desa Padang Pelasan Kecamatan Air Periukan Kabupaten Seluma.

2. Menentukan waktu pelaksanaan kegiatan pelatihan tentang pelatihan keterampilan dasar dan teknologi informasi bagi perangkat desa khususnya Desa Padang Pelasan Kecamatan Air Periukan Kabupaten Seluma.

3. Menghubungi atau menginformasikan kepada seluruh perangkat Keluarahaan untuk berkena hadir pada saat dan waktu yang telah ditentukan sesuai dengan undangan yang terlampir.

4. Mempersiapkan konsep kegiatan dan mempersiapkan prasarana yang dibutuhkan.

b. Pelaksanaan :

1. Setelah semua telah berkumpul, acara akan dimulai pada pukul 08.00 WIB dilakukan presentasi dengan media power point dengan perangkat LCD dengan dipancarkan ke dinding.

2. Membagi modul yang telah dibuat kepada para peserta dan telah diperbanyak sesuai jumlah peserta yang ada.

3. Diberikan materi dalam bentuk teori dan disajikan dalam bentuk presentasi didepan peserta.

4. Kemudian dilanjutkan dengan praktek secara langsung dengan perangkat komputer yang telah disediakan, juga dalam kesempatan ini kepada peserta diberikan kesempatn untuk
Tanya jawab yang berhubungan dengan materi yang telah disampaikan.

5. Acara selesai pada pukul 16.00

\subsection{Pemecahan Masalah}

Metode pelaksanaan dengan cara langsung melakukan pelatihan dan Praktek dengan urutan sebagai berikut:

1. Melakukan Koordinasi dengan Aparat desa Khususnya Kepala desa dan perangkatnya

2. Membarikan pembekalan ke tim dalam Penguasaan materi yang akan diberikan dan mempersiapkan perangkat apa saja yang dibutuhkan.

3. Membuat penjadwalan pendampingan belajar seraca bertahap dengan peserta dalam hal ini Aparat Desa Padang Pelasan Kecamatan Air Periukan Kabupaten Seluma.

4. Melakukan pelatihan secara bersama berupa materi dasar komputer, office dan Internet

5. Mengevaluasi hasil pelatihan dengan melihat hasil kerja praktek yang dilakukan.

Metode kegiatan yang digunakan pada program kegiatan ini diharapkan dapat memberikan kemudahan kepada peserta kegiatan. Dalam kegiatan ini, metode yang digunakan adalah metode penjelasan, sharing, tanya jawab, diskusi dan praktik. Pada metode penjelasan, setiap instruktur menyampaikan materi terkait dan membuat tampilan visual berupa slide power point yang ditampilkan ke layar dengan alat LCD proyektor. Modul ringkas kegiatan dan alat tulis dibagikan kepada peserta kegiatan agar peserta memiliki pegangan untuk dibaca yang dapat langsung ditambahkan dengan catatan-catatan yang mereka perlukan. Instruktur dalam menyampaikan penjelasan juga memasukkan unsur "sharing" atau berbagi pengalaman 
mengenai penggunaan Komputer, Office dan Internet sehingga dapat memberikan gambaran lebih jelas kepada peserta. Pada metode praktik, peserta membawa perangkat Komputer (Laptop) yang tersambung ke internet untuk sama-sama berlatih. Peserta diajarkan bagaimana cara membuat menjalan Komputer, dasar Office dan Penggunaan Internet.

Pada sesi satu, peserta diajarkan bagai mana dasar-dasar komputer yang meliputi pengenalan perangkatperangkat komputer dan cara menghidupkan/mematikan komputer sebagai langkah awal sebelum melakukan materi yang lainnya.

Sesi dua panduan dasar menjalankan Office Word Untuk menjalankan MS Word diperlukan langkah sebagai berikut: hidupkan komputer / Laptop buka icon MS Word, Cara mengetik - Untuk mulai menulis di MS Word maka yang dilakukan adalah dengan langsung mengetik menggunakan keyboard. Bila kursor belum tampak maka cukup klik dulu dengan 'klik kiri / biasa' di baris paling atas halaman yang berwarna putih polos tersebut agar ketikannya mulai dari baris awal. Lebih lengkapnya baca : Panduan Lengkap Cara Mengetik Di Komputer PC dan Laptop, Cara Menghapus Kata atau Kalimat - Untuk melakukan ini maka cukup dengan meletakkan kursor di depan tulisan (sebelah kiri kata pertama) lalu tekan tombol "Delete" di keyboard atau bisa juga letakkan kursor di sebelah kiri (belakang kata) dari kata atau kalimat yang akan dihapus lalu tekan tombol "Backspace" di keyboard. Bisa juga dalam belajar MS word ini kita mencari jalan pintas, misalnya pada cara ini kita cukup blok dulu kalimat atau paragraf yang akan dihapus lalu tekan tombol 'delete', Cara Membuat Paragraf Baru atau pindah ke baris selanjutnya Misalnya saja sudah selesai menulis 1 kalimat lalu mau lanjut di baris selanjutnya maka cukup tekan tombol "Enter" di keyboard, Cara Membuat Huruf besar dan kecil - Caranya tekan tombol "Caps Lock" yang ada di sebelah kiri Keyboard. Tekan sekali untuk mengaktifkan huruf Besar atau Kapitalnya dan tekan sekali lagi untuk mengembalikan jadi huruf kecil lagi, Cara Copy-Paste - Seringkan dengar istilah ini. Caranya cukup Blok dulu tulisannya kemudian tekan tombol Ctrl di pojok kiri bawah dan huruf $\mathrm{C}(\mathrm{Ctrl}+$ C) di keyboard (ini untuk meng-copy tulisan). Selanjutnya untuk mempaste (memunculkan tulisan di halaman lain) caranya cukup buka file ms Word yang akan menjadi tempat menyimpan (mempaste) lalu setelah itu klik dulu di baris dimana kita akan meletakkan kalimat yang kita copy, selanjutnya tinggal tekan $\mathrm{Ctrl}+\mathrm{V}$. klik kanan di mouse lalu pilih “Copy'. Demikian juga kalau mau dipaste, diblok lalu klik kanan dan pilih menu 'Paste', Cara Blok Tulisan - Cara ini dilakukan untuk memilih kata, kalimat, atau paragraf tertentu yang akan diedit, apakah itu mengganti jenis hurufnya, memperbesar atau memperkecil tulisannya, mengcopy atau apa pun tujuannya. menentukan kata tertentu yang akan diubah atau diedit. Caranya cukup klik di bagian depan kata atau kalimatnya lalu tekan dan jangan dilepas, selanjutnya tinggal tarik kursornya hingga ke bagian akhir yang akan diblok.

Memulai Microsoft Excel, Untuk memulai menggunakan aplikasi Microsoft Excel, ada beberapa cara yang bisa Anda gunakan diantaranya adalah sebagai berikut : Klik tombol Start pada Taskbar Komputer, Pilih menu All Program, Pilih Microsoft Office, Kemudian klik Microsoft Excel 2007 


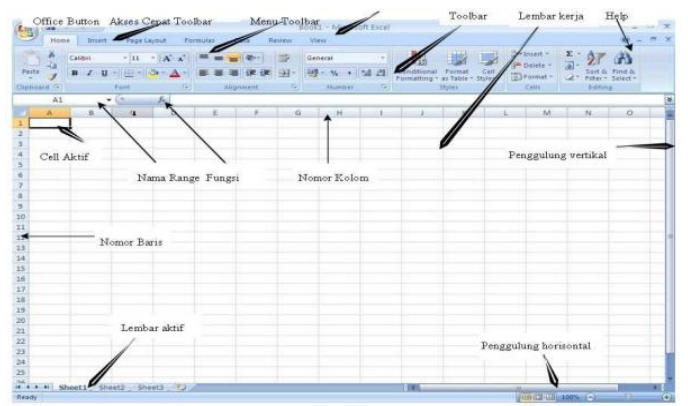

Gambar 2.1. Gambar Tampilan

Microsoft Excel 2007

Unsur-unsur utama Layar Microsoft Excel 2007 : Judul Judul menampilkan judul program dan dokumen aktif atau nama file dari lembar kerja yang aktif. Office Button Berisi barisan perintah untuk pengoperasian Program yang standar misalnya membuat dokumen baru, membuka dokumen lama, menyimpan, mencetak dan mempublish dokumen.

Akses Cepat Toolbar (Quick Access Toolbar) Merupakan sarana yang disediakan Microsoft Excel untuk mempercepat akses berkomunikasi dengannya misalnya menyimpan, mencetak dan sebagainya Toolbar Merupakan deretan tool-tool (gambargambar) yang mewakili perintah dan berfungsi untuk mempermudah dan mengefisienkan pengoperasian program.

Help Bila kita ingin bertanya sesuatu, maka ketik pertanyaan anda pada tempat tersebut. Ms Excel akan memberikan alternatif jawaban terhadap pertanyaan yang dimaksud. Lembar Kerja (Workbook) Baris ini berisikan informasi halaman, section, letak insertion point dan tombol pengendali. Cell Cell merupakan Nomor Baris Nomor Kolom Nama Range Fungsi Penggulung vertical dan horisontal Untuk memudahkan dalam membaca suatu dokumen dengan menggulung layar vertikal dan horisontal.

Sesi tiga pengenalan penggunaan internet dan perangkatperangkat yang dibutuhkan dan keterhubungan jaringan pada komputer yang digunakan, mulai dari pembuatan email, pembuatan media sosial dan pembuatan blog, Dalam tutorial ini, ada tiga tahapan yang harus dilakukan, ketiga tahap ini harus dilalui dan seluruh isi blog di sunting sendiri : Hal paling pertama yang dilakukan sebelum membuat blog adalah persiapan. Apa saja yang harus disiapkan, tentu saja yang paling utama adalah perangkatnya, misal komputer atau notebook yang tentu saja tersambung dengan internet. Kalau tak memiliki, Anda bisa menyewanya di warnet. Setelah semua alat telah siap. Tahap selanjutnya adalah menentukan tujuan. Ada dua tujuan dasar seseorang membuat blog. Sebagai sarana berbagi catatan, hobby dengan komunitas atau bahkan sebagai tempat curhat,.

Setelah sedikit banyaknya mengetahui tentang blog dan melakukan riset atas tema blog yang akan dibuat, tahap selanjutnya tentu saja membangunnya. Membuat blog, utamanya Blogspot amat sangat mudah dan semua disediakan secara gratis.

Tabel 2.1 Materi Kegiatan dan Instruktur

\begin{tabular}{|c|c|c|c|}
\hline No & Materi & Intruktur & Waktu \\
\hline 1 & Pembukaan dan Sambutan & $\begin{array}{l}\text { Ketua : Agusdi Syafrizal, } \\
\text { M.Kom } \\
\end{array}$ & 30 Menit \\
\hline 2 & Sosialisasi Microsoft Word & Rozali Toyib, M.Kom & 120 Menit \\
\hline 3 & Sosialisasi Microsoft Excel & Yulia Damita, M. Kom & 120 Menit \\
\hline 4 & $\begin{array}{l}\text { Pemanfaatan Microsof Word } \\
\text { dalam Pembuatan Proposal }\end{array}$ & Rozali Toyib, M.Kom & 120 Menit \\
\hline 5 & $\begin{array}{l}\text { Pemanfaatan Microsof Excel } \\
\text { dalam Pembuatan } \\
\text { Pembukuan } \\
\text { sederhana }\end{array}$ & Yulia Darnita, M. Kom & 120 Menit \\
\hline 6 & Penggunaan Internet & Agusdi Syafrizal, M.Kom & 90 Menit \\
\hline 7 & Pembuatan Blog & Agusdi Syafrizal, M.Kom & 120 Menit \\
\hline 8 & $\begin{array}{l}\text { Sharing, Tanya Jawab, } \\
\text { diskusi }\end{array}$ & $\begin{array}{l}\text { Agusdi Syafrizal, M.Kom, } \\
\text { Rozali Toyib, M.Kom } \\
\text { Yulia Darnita, M,Kom }\end{array}$ & 120 Menit \\
\hline
\end{tabular}

\section{HASIL DAN PEMBAHASAN}

Pelaksanaan PKM Pengabdian ini dilaksanakan selama 3 hari terhitung mulai tanggal 20 - 22 Maret 2018 . Tahapan pencapaian target hasil diuraikan menurut runtutan metode pelaksanaan dengan beberapa modifikasi sesuai kondisi lapangan, dan selanjutnya secara detail diuraikan berikut. Tim PKM melakukan 
pertemuan dengan Kepala Desa Padang Pelasan Konsultasi dengan Kepala Desa Padang Pelasan mengenai situasi dan kondisi desa Padang Pelasan dan budaya masyarakat setempat.

\subsection{Pembekalan Peserta (Coaching)}

Pembekalan peserta ditujukan untuk memberikan pemahaman dasar atas tema yang diusung, pelatihan penggunaan modul serta penentuan hari dilokasi, Memberikan gambaran umum kondisi desa yang akan ditempati. Pembekalan dilakukan pada tanggal 2022 maret 2018 di ruang kuliah yang ada

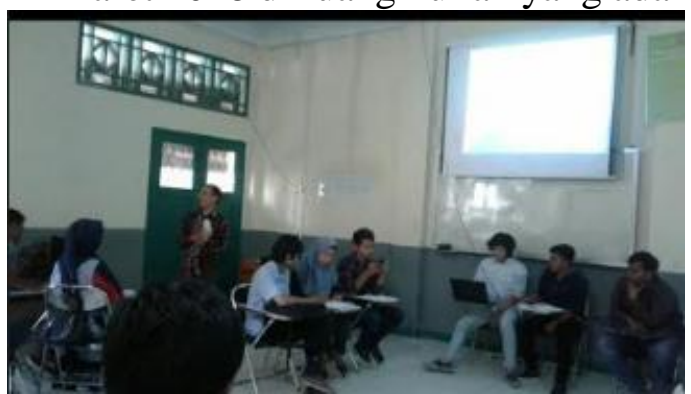

Gambar 3.1. Koordinasi Awal Tim dan Pendukung

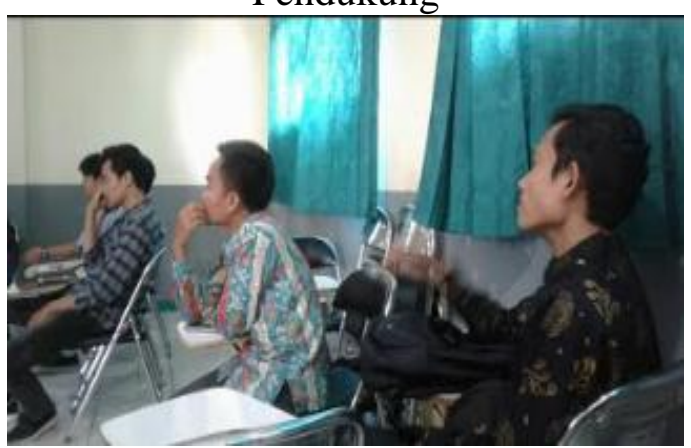

Gambar 3.2. Pemantapan

\subsection{Pelaksanaan Program}

Selanjutnya

mahasiswa melakukan pelatihan komputer untuk Perangkat Desa Padang Pelasan. Kegiatan ini diikuti oleh staf desa dan kepala-kepala dusun serta beberapa masyarakat setempat. Pelatihan ditujukan untuk bagaimana Pengenalan Dasar Kompute, mengoptimalkan penggunaan Microsoft Office khususnya Word, Excel dan Internet. Berikut gambar saat pelaksanaan pelatihan keterampilan komputer untuk perangkat desa.

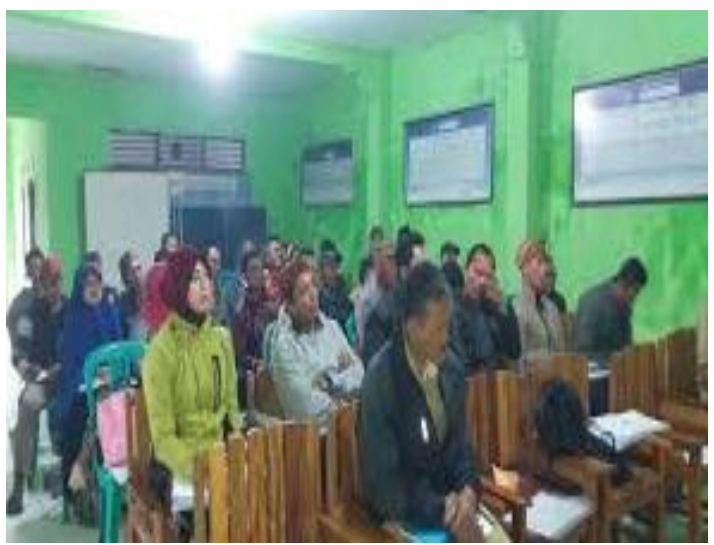

Gambar 3.3. Peserta
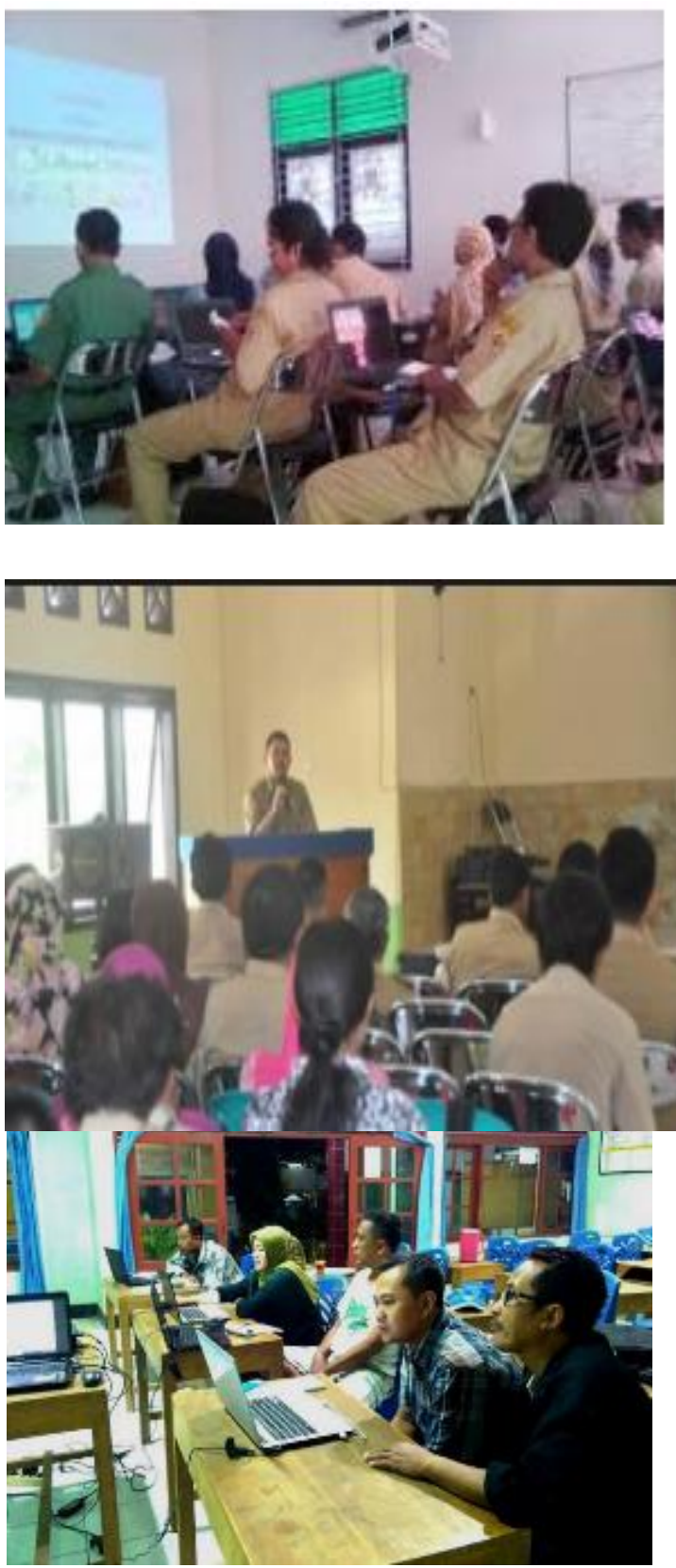

Gambar 3.6. Menyimak dan

Memperhatikan 


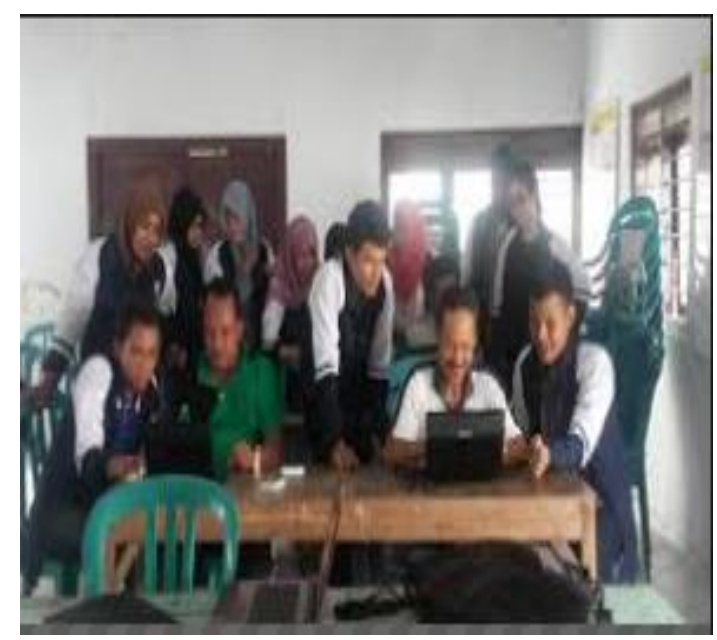

Gambar 3.7. Diskusi Kelompok

\subsection{Hasil}

Hasil capaian kegiatan PKM Pengabdian Desa Padang Pelasan 2018, setelah semua rangkaian kegiatan telah dilaksanakan dengan mencapai hasil 80 $\%$ sesuai dengan laporan bukti kegitan yang telah dilaksanakan

\subsection{Monitoring}

Monitoring dilakukan untuk memastikan bahwa semua proses berjalan sesuai dengan yang diharapkan dan dapat menemuh permasalahan dan hambatan secara dini sehingga tidak berdampak yang merugikan pada keberlangsungan pelaksanaan program. Untuk kegiatan PKM Pengabdian di Desa Padang Pelasan ini mekanisme monitoring dilakukan secara rutin dalam bentuk kunjungan lapangan,pada proses monitoring memberikan petunjuk dan arahan akan keberlangsungan kegiatan dan koordinasi dengan kepala desa dan aparat desa.

\subsection{Evaluasi}

Evaluasi dilakukan untuk menilai pencapaian semua proses perencanaan mulai dari tahapan persiapan sampai pelaporan. Evaluasi dilakukan dengan mengacu pada kehadiran, keaktifan peserta dan beban kerja masing-masing peserta dibuktikan dengan daftar kehadiran peserta dan / laporan aktifitas harian selama mengikuti PKM Pengabdian.

\section{PENUTUP}

\subsection{Kesimpulan}

Berdasarkan hasil kegiatan pengabdian masyarakat di lokasi mitra, maka dapat disimpulkan bahwa:

a. Perangkat Desa sangat antusias mengikuti pelatihan

b. Adanya Peningkatan dalam melakukan pekerjaan administrasi dan keuangan desa

c. Internet menjadi bagian penting bagi mereka untuk memperoleh informasi penting.

d. Akses Internet Lambat karena jauh dari provider

e. Keterbatasan prasarana khususnya perangkat komputer yang ada di Kantor Desa.

\subsection{Saran}

Sesuai dengan hasil yang telah dilaksanakan maka perlu ada perbaikan dari segi sarana dan pra sarana dan SDM baik dari pendamping maupun dari peserta.

\section{DAFTAR PUSTAKA}

1. Azmeri, Dr., ST., MT, Ahmad Reza Kasury, ST., MT., Halida Yunita, Dr.,ST., MT. 2017. Ibm Desa Beureunut Dan Ujong Keupula Akibat Kekurangan Air Bersih Pasca Bencana Banjir Bandang Melalui Teknologi Penyediaan Air Bersih Berbasis Pemberdayaan Masyarakat Perempuan, Laporan Tahun Terakhir Program Kemitraan Masyarakat (Pkm), Universitas Syiah Kuala.

2. Fatimah Zuhrah. 2011. Pentingnya Teknologi Informasi Dalam Meningkatkanpelayanan Di Perpustakaan, Jurnal Iqra' Volume 05 No.01, IAIN-SU. 
3. Asroni, S.T., M.Eng. Haris Setyawan, S.T., M.Eng. 2016. Pelatihan MS Office dan Pembuatan Blog Di Dusun Kalitengah Lor, Glagaharjo, Cangkringan Sleman, Laporan Kegiatan Pengabdian Masyarakat, Fakultas Teknik Universitas Muhammadiyah Yogyakarta

4. Dokumen Pemerintah Provinsi Bengkulu. 2017. Rencana Aksi Daerah Percepatan Pembangunan Daerah Tertinggal.

5. Dedi Purwana ES, Rahmi Shandy Aditya. 2017. Pemanfaatan Digital Marketing Bagi Usaha Mikro, Kecil, Dan Menengah (Umkm) Di Kelurahan Malaka Sari, Duren Sawit, Jurnal Pemberdayaan Masyarakat Madani (JPMM), 1(1).

6. Jenji Gunaedi A, Heni Nastiti, Erly Krisnanik (2017), Ibm SME Berbasis Online Marketing, Prosiding SNaPP2017 Sosial, Ekonomi, dan Humaniora.

7. Tona Aurora Lubis, Junaidi. 2016. Pemanfaatan Teknologi Informasi Pada Usaha Mikro Kecil Dan Menengah Di Kota Jambi, Jurnal Perspektif Pembiayaan dan Pembangunan Daerah Vol. 3 No. 3.

8. Rr. Tri Istining Wardani. 2017. Data Siswa Pada Guru Smpk Pelatihan Aplikasi Ms Excel Untuk Efisiensi Pengelolaan Setia Budi - Malang, JABDIMAS, 4(1): 2407-4357 